\title{
Soil quality in two coffee crop systems in the Amazon biome
}

\author{
Nirvani S. Henrique ${ }^{1}$, Katia L. Maltoni ${ }^{2} \&$ Glaucia A. Faria ${ }^{3}$ \\ ${ }^{1}$ Instituto Federal de Educação, Ciência e Tecnologia de Rondônia, Câmpus Cacoal, RO, Brasil. E-mail: nirvani.henrique@ifro.edu.br (Corresponding \\ author) - ORCID: 0000-0003-3208-5910 \\ ${ }^{2}$ Universidade Estadual Paulista/Faculdade de Engenharia/Departamento de Fitossanidade, Engenharia Rural e Solos, Ilha Solteira, SP, Brasil. E-mail: \\ katia.maltoni@unesp.br - ORCID: 0000-0001-6619-4504 \\ ${ }^{3}$ Universidade Estadual Paulista/Faculdade de Engenharia/Departamento de Matemática, Ilha Solteira, SP, Brasil. E-mail: glaucia.a.faria@unesp.br - \\ ORCID: 0000-0003-2474-4840
}

\begin{abstract}
The form of occupation of the state of Rondônia, Brazil, favored the extensive agriculture, which resulted in a fast deforestation. The removal of forests and inadequate soil management and use, combined with a hot and wet climate, affected the soil chemical, physical, and biological attributes. In search for less impacting and alternatives that promote greater soil conservation for coffee production in the North region of Brazil, the objective of this work was to evaluate the effects of two coffee crop systems on the soil chemical and microbiological attributes. The treatments consisted of a shaded coffee crop (SCC) and a fullsun coffee crop (FCC). A completely randomized design was used, with four clusters per treatment and seven sampling points per cluster, which constituted a replication, totaling 28 replications per treatment. The data were collected in April 2018, in a rural property in the municipality of Cacoal, state of Rondônia, Brazil (11 $21^{\prime} 50^{\prime \prime} \mathrm{S}, 61^{\circ} 20^{\prime} 10^{\prime \prime} \mathrm{W}$, and altitude of $238 \mathrm{~m}$ ). The soil organic matter, $\mathrm{pH}, \mathrm{P}, \mathrm{K}, \mathrm{Ca}, \mathrm{Mg}, \mathrm{Al}, \mathrm{H}+\mathrm{Al}$, base saturation, and basal respiration were determined. The soil under SCC had higher Ca content, $\mathrm{pH}$, and base saturation, and lower potential acidity $(\mathrm{H}+\mathrm{Al})$ and $\mathrm{Al}$ content than that under FCC. The litterfall on the soil under FCC presented higher $\mathrm{N}$ and $\mathrm{Mg}$ contents. The soil basal respiration increased in the first $5 \mathrm{~cm}$ depth in the treatment with SCC.
\end{abstract}

Key words: Coffea canephora, shading, sustainability

\section{Qualidade do solo em dois sistemas de cultivo do cafeeiro no domínio Amazônico}

RESUMO: A forma de ocupação do Estado de Rondônia, favoreceu a agricultura extensiva, o que resultou em desmatamento acelerado. A retirada da floresta, o manejo e uso inadequado do solo, associado ao clima quente e úmido afetaram os atributos químicos, físicos e biológicos dos solos. Buscando alternativas menos impactantes e de maior conservação do solo para produção de café na região Norte, objetivouse nesta pesquisa avaliar os efeitos de dois sistemas de cultivo do cafeeiro, sobre a qualidade química e microbiológica do solo. Os tratamentos foram cultivo sombreado (CS) e a pleno sol (CPS). O delineamento estatístico utilizado foi o inteiramente casualizado, com quatro aglomerados para cada tratamento e sete pontos amostrais em cada aglomerado que constituem as repetições, totalizando 28 repetições para cada tratamento. A coleta de dados ocorreu em abril de $2018 \mathrm{em}$ uma propriedade rural do município de Cacoal, RO, localizada a $11^{\circ} 21^{\prime} 50^{\prime \prime} \mathrm{S}$ e $61^{\circ} 20^{\prime} 10^{\prime \prime} \mathrm{O}$, e altitude de $238 \mathrm{~m}$. A matéria orgânica (MO), pH, fósforo $(\mathrm{P})$, potássio $(\mathrm{K})$, cálcio $(\mathrm{Ca})$, magnésio $(\mathrm{Mg}), \mathrm{H}+\mathrm{Al}^{3+}$, alumínio $\left(\mathrm{Al}^{3+}\right)$, saturação por bases $(\mathrm{V})$ e a respiração basal do solo (RBS) foram determinados. O solo sob CS tem maior teor de Ca, pH e V (\%) e menor acidez potencial e $\mathrm{Al}^{3+}$, em comparação ao CPS. A serapilheira sob CPS apresenta maiores teores de $\mathrm{N} \mathrm{e} \mathrm{Mg} \mathrm{e} \mathrm{a} \mathrm{respiração} \mathrm{basal} \mathrm{do} \mathrm{solo} \mathrm{aumentou} \mathrm{no} \mathrm{sombreamento} \mathrm{nos} \mathrm{primeiros} 5 \mathrm{~cm}$ de profundidade.

Palavras-chave: Coffea canephora, sombreamento, sustentabilidade 


\section{INTRODUCTION}

Coffee crop is important for rural proprieties with family basis in the state of Rondônia, Brazil; however, there is a greater focus on this activity in some periods because of the high price of coffee beans, and a lower focus on some periods due to the low prices. Considering this context, agroforestry systems have been introduced, and those focused on ecological and economic benefits and on sustainability (Rodrigues et al., 2015) have been established.

Shaded coffee crops grown in environments within the Atlantic Forest biome showed higher leaf area, number of branches, leaf nitrogen content, green fruit percentage, plant height, canopy diameter, number of leaves in the branches, and distance between nodes than coffee crops grown under full sun, without decreasing yield (Ricci et al., 2011). Pinto Neto et al. (2014) evaluated biomass and yield of coffee plants under different shading systems and found that a mean shading (68\%) is more adequate to coffee crops than intense shading (84\%).

Soil chemical, physical, and biological quality indicators are related to organic matter contents (Han et al., 2016), which has important functions in the complexation of substances, and supplying and storage of nutrients and water for the plants (Pezarico et al., 2013). Therefore, the adoption of management systems that increase stocks of organic residues in the soil or in the soil surface are essential to maintain and improve the soil quality (Stefanoski et al., 2013).

Thus, the objective of this work was to evaluate the effects of two coffee crop systems on the soil chemical and microbiological attributes.

\section{Material ANd Methods}

The municipality of Cacoal, state of Rondônia, Brazil, was selected for this study because it presents 3,814 agricultural properties, from which 1,391 are coffee producers, and 53\% of the rural properties have coffee crops in Cacoal, and a total of 4,683 hectares of its area is grown with coffee plants (IBGE, 2017). The most common soil class found in the region is Ultisol, with medium to clayey texture.
The climate of the whole state of Rondônia is Am (monsoon), according to the Köppen classification, with mean annual rainfall depths of 1,400 to $2,600 \mathrm{~mm}$ and mean air temperature of 24 to $26^{\circ} \mathrm{C}$ (Alvares et al., 2013).

The study was conducted at a rural property in Cacoal $\left(11^{\circ} 21^{\prime} 50^{\prime \prime S}\right.$ and $61^{\circ} 20^{\prime} 10^{\prime \prime} \mathrm{W}$, and altitude of $\left.238 \mathrm{~m}\right)$. Two areas with coffee plants were chosen for the study (Figure 1), which were managed differently and defined as follows: Treatment 1 = soil cultivated with an agroforest system with coffee plants (Coffea canephora) and teak (Tectona sp.), which was called shaded coffee crops (SCC); and Treatment 2 = soil cultivated with coffee crops at full sun, which was called full-sun coffee crop (FCC).

The plants of the full-sun coffee crop were planted with spacing of $3 \mathrm{~m}$ between rows and $2.5 \mathrm{~m}$ between plants. The soil had been fertilized annually with mineral fertilizers consisting of $\mathrm{N}$ ( $48 \mathrm{~kg} \mathrm{ha}^{-1}$ of $\left.\mathrm{N}\right), \mathrm{P}\left(12 \mathrm{~kg} \mathrm{ha}^{-1}\right.$ of $\mathrm{P}_{2} \mathrm{O}_{5}$ ), and $\mathrm{K}$ ( $48 \mathrm{~kg} \mathrm{ha}^{-1}$ of $\mathrm{K}_{2} \mathrm{O}$ ), without considering the soil chemical analysis. Weeds were controlled using a grass cutter machine and applications of glyphosate herbicide. The area was irrigated using a sprinkler system to promote the anthesis of the flowers. The coffee crops had never been renewed since the planting; however, the branches of the plants in the FCC had been pruned once a year, after the coffee harvest, and thinned manually twice a year in the rainy period.

Each coffee crop system (SCC and FCC) was divided into four clusters of $24 \times 27 \mathrm{~m}$, encompassing seven soil sampling points, which constituted the replications, totaling 28 replications per planting system.

Soil samples of the $0-5$ and 5-10 cm layers were collected and sieved in 2-mm mesh sieves. Part of these samples were used to determine the soil basal respiration, and other part was air-dried to obtain the bulk soil for the analyses of organic matter content (Walkley-Black method), $\mathrm{pH}$ (in solution of $\mathrm{CaCl}_{2}$ ), and $\mathrm{P}, \mathrm{K}, \mathrm{Ca}$, and $\mathrm{Mg}$ contents (resin method), acidity potential ( $\mathrm{H}+\mathrm{Al}$; determined in a SMP buffer solution), and Al content (Raij et al., 2001).

The soil basal respiration was quantified in $50 \mathrm{~g}$ of soil, which were placed in glass jars with a flask in the center containing $10 \mathrm{~mL}$ of $\mathrm{NaOH} 0.1 \mathrm{M}$; the jars were then

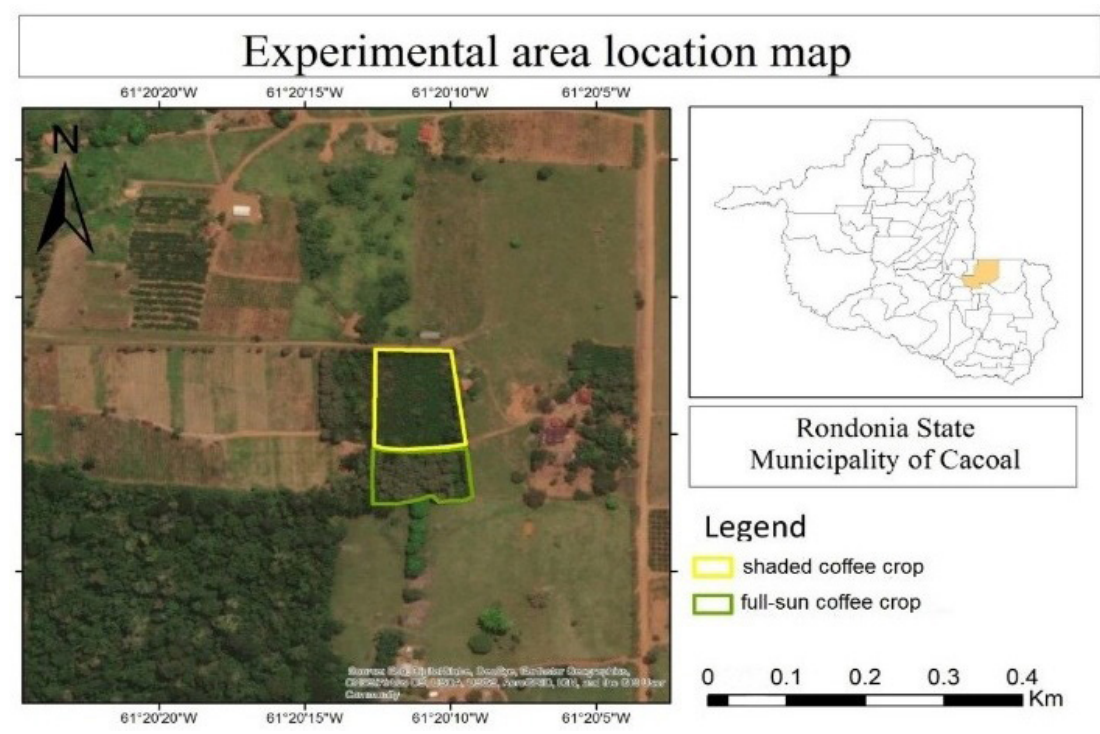

Figure 1. Location of the site selected for the study, with soils under shaded coffee crop and full-sun coffee crop 
hermetically closed. The incubation time was $173 \mathrm{~h} . \mathrm{HCl}$ $(0.1 \mathrm{M})$ and phenolphthalein $(1 \%)$ was used as indicator for titration of free $\mathrm{NaOH}$. The control was prepared in glass jars without soil, containing flasks with $\mathrm{NaOH}$. The titration of the free base allowed the calculation of the quantity of $\mathrm{CO}_{2}$ that reacted with the $\mathrm{NaOH}$ and, thus, the $\mathrm{C}-\mathrm{CO}_{2}$ released by the microbial respiration (Silva et al., 2007).

Litterfall samples were collected in both treatments, totaling eight replications per area. These samples were dried at $65^{\circ} \mathrm{C}$ until constant weight, ground in a mill, and used to determine the N, P, K, Ca, Mg, and S contents, following the methodology described by Malavolta et al. (1997).

The results were subjected to the Shapiro-Wilk normality test, using the $\mathrm{R}$ program ( $\mathrm{R}$ Core Team, 2015). The results of organic matter $(0-5 \mathrm{~cm}), \mathrm{P}, \mathrm{pH}(5-10 \mathrm{~cm}), \mathrm{Ca}(5-10 \mathrm{~cm})$, $\mathrm{Mg}$, and $\mathrm{H}+\mathrm{Al}(5-10 \mathrm{~cm})$ presented no normal distribution and were transformed to $\log (y)$. Subsequently, the data were subjected to the F test by analysis of variance for each layer evaluated, using the Sisvar 5.6 program (Ferreira, 2014).

\section{Results AND Discussion}

The organic matter contents in both treatments and soil layers evaluated were similar (Table 1); however, in SCC there was senescence of teak leaves, which formed a thick litterfall layer on the soil, and in FCC there was residues of the pruning (orthotropic and plagiotropic branches, and leaves), which also form a litterfall layer contributing, similarly, to add organic matter to the first $10 \mathrm{~cm}$ of soil in both crop systems.

The similarity between organic matter contents in this case can be attributed to the absence of pruning residues and to the higher microbial activity in SCC (Table 2). Moreover, the plant biomass in this treatment presents lower $\mathrm{C}$ to $\mathrm{N}$ ratio (Acosta et al., 2014) due to the teak leaves, which, combined to the temperature and humidity conditions, lead to a faster mineralization of the organic matter (Guimarães et al., 2017). These factors caused less or similar organic matter contents in the soil under SCC than those in the soil under FCC, where the pruning residues resulted in a plant biomass with probably higher $\mathrm{C}$ to $\mathrm{N}$ ratio and lower microbial activity (Table 2).

Monoculture systems such as FCC are more susceptible to decreases in organic matter contents due to a lower constant deposition of organic materials on the soil. This denotes the positive effect of agroforest systems over time (Ilany et al.,
Table 2. Basal respiration (SBR) of soils under full-sun coffee crop (FCC) and shaded coffee crop (SCC), sampled from the layers $0-5$ and $5-10 \mathrm{~cm}$

\begin{tabular}{lcc}
\hline \multirow{2}{*}{$\begin{array}{c}\text { Cultivation } \\
\text { systems }\end{array}$} & \multicolumn{2}{c|}{ Depth $(\mathrm{cm})$} \\
\cline { 2 - 3 } & $\mathbf{0 - 5}$ & $\mathbf{5 - 1 0}$ \\
\hline SCC & \multicolumn{2}{c|}{$\left(\mathrm{CO}_{2} \mathrm{mg} \mathrm{kg}^{-1} \mathbf{d}^{-1}\right)$} \\
FCC & $18.22 \mathrm{a}$ & $7.07 \mathrm{a}$ \\
CV (\%) & $16.71 \mathrm{~b}$ & $6.94 \mathrm{a}$ \\
F Values & 14 & 27 \\
\hline & $5.22^{\star}$ & $0.07^{\text {ns }}$ \\
\hline
\end{tabular}

Means followed by the same lowercase letter in the columns, within the same layer, are not different by the $\mathrm{F}$ test at $\mathrm{p} \leq 0.05$

2010). This effect was not found in the present study, probably because of the evaluation time, which was in the beginning of autumn.

The phosphorus contents in the treatments were different, with higher contents in FCC, where the soil has been fertilized annually with $\mathrm{P}$ by surface applications. This favored the high contents of this nutrient, since it is little mobile in the soil (Iwata et al., 2012). Haggar et al. (2011) also found significantly higher $\mathrm{P}$ contents in coffee crops cultivated under full sun, when compared to coffee plants under shaded systems, due to fertilizer applications.

The treatments had no effect on $\mathrm{K}$ contents in any of the evaluated soil layers (Table 1), despite the application of $48 \mathrm{~kg}$ of $\mathrm{K}_{2} \mathrm{O} \mathrm{ha} \mathrm{ha}^{-1}$ year $^{-1}$ in the FCC area and lack of soil fertilization in SCC, denoting the maintenance of $\mathrm{K}$ contents in SCC by means of nutrient cycling, probably because of the presence of litterfall (Lima et al., 2015).

The Ca content in the $0-5 \mathrm{~cm}$ soil layer in SCC was higher than that in FCC. However, no differences were found between the treatments in the $5-\mathrm{cm}$ layer. However, the magnesium contents in the two soil layers analyzed was higher in FCC (Table 1), and varied from medium to satisfactory for the development of most crops (Ribeiro et al., 1999) in both SCC and FCC.

The base saturation was higher in SCC in the $0-5 \mathrm{~cm}$ soil layer, not differing from that in FCC in the 5-10 layer (Table 1); this can be attributed to the presence of litterfall and nutrient cycling, whose efficiency is dependent on the litterfall quality, time, crop system established, and biotic and abiotic factors (Acosta et al., 2014).

The potential acidity $(\mathrm{H}+\mathrm{Al})$ and $\mathrm{Al}$ contents were higher in FCC. The base saturation was higher in the $0-5 \mathrm{~cm}$ soil

Table 1. Organic matter (OM), phosphorus $(\mathrm{P}), \mathrm{pH}$, exchangeable bases ( $\mathrm{K}, \mathrm{Ca}$, and $\mathrm{Mg})$, potential acidity $(\mathrm{H}+\mathrm{Al}), \mathrm{Al}$, and base saturation (V) in soils under full-sun coffee crop (FCC) and shaded coffee crop (SCC), sampled from the layers 0-5 and 5-10 cm

\begin{tabular}{|c|c|c|c|c|c|c|c|c|c|}
\hline $\begin{array}{c}\text { Cultivation } \\
\text { systems }\end{array}$ & $\begin{array}{c}\mathrm{OM} \\
\left.(\mathrm{g} \mathrm{dm})^{-3}\right)\end{array}$ & $\begin{array}{c}\mathbf{P} \\
\left(\mathrm{mg} \mathrm{dm^{-3 } )}\right)\end{array}$ & $\begin{array}{c}\mathrm{pH} \\
\left(\mathrm{CaCl}_{2}\right)\end{array}$ & $K$ & $\mathrm{Ca}$ & $\frac{\mathrm{Mg}}{\mathrm{mol}_{\mathrm{c}} \mathrm{dr}}$ & $\mathrm{H}+\mathrm{Al}$ & $\mathrm{Al}$ & $\begin{array}{c}V \\
(\%)\end{array}$ \\
\hline & & & & & $0-5 \mathrm{~cm}$ & & & & \\
\hline SCC & $41.9 \mathrm{a}$ & $10.1 \mathrm{~b}$ & $5.4 \mathrm{a}$ & $0.24 \mathrm{a}$ & $7.2 \mathrm{a}$ & $1.3 b$ & $2.5 \mathrm{~b}$ & $0.02 \mathrm{~b}$ & $77.1 \mathrm{a}$ \\
\hline FCC & $41.5 \mathrm{a}$ & $20.5 \mathrm{a}$ & $4.9 \mathrm{~b}$ & $0.22 \mathrm{a}$ & $5.6 \mathrm{~b}$ & $1.5 \mathrm{a}$ & $3.9 \mathrm{a}$ & $0.12 \mathrm{a}$ & $64.6 \mathrm{~b}$ \\
\hline CV (\%) & 4.5 & 19.7 & 4.9 & 27.6 & 20.5 & 8.8 & 18.3 & 94.7 & 9.7 \\
\hline \multirow[t]{2}{*}{ F Values } & $0.06^{\mathrm{ns}}$ & $14.6^{* *}$ & $45.0^{\star \star}$ & $1.3^{\text {ns }}$ & $18.6^{\star *}$ & $8.6^{* \star}$ & $84.8^{\star *}$ & $31.2^{\star *}$ & $45.6^{\star *}$ \\
\hline & \multicolumn{9}{|c|}{$5-10 \mathrm{~cm}$} \\
\hline SCC & $27.5 \mathrm{a}$ & $6.1 \mathrm{~b}$ & $5.1 \mathrm{a}$ & $0.23 \mathrm{a}$ & $3.8 \mathrm{a}$ & $0.8 \mathrm{~b}$ & $3.0 \mathrm{~b}$ & $0.10 \mathrm{~b}$ & $60.8 \mathrm{a}$ \\
\hline FCC & $27.8 \mathrm{a}$ & $18.8 \mathrm{a}$ & $4.9 b$ & $0.20 \mathrm{a}$ & $3.7 \mathrm{a}$ & $1.0 \mathrm{a}$ & $3.7 \mathrm{a}$ & $0.15 a$ & $56.2 \mathrm{a}$ \\
\hline CV (\%) & 4.4 & 34.2 & 3.6 & 31.3 & 8.9 & 10.9 & 5.0 & 56.7 & 15.7 \\
\hline F Values & $0.3^{\text {ns }}$ & $14.0^{* *}$ & $7.1^{*}$ & $2.7^{\mathrm{ns}}$ & $0.03^{\text {ns }}$ & $8.2^{*}$ & $22.6^{* *}$ & $5.82^{\star}$ & $3.46^{\text {ns }}$ \\
\hline
\end{tabular}

Means followed by the same lowercase letter in the columns, within the same layer, are not different by the $\mathrm{F}$ test at $\mathrm{p} \leq 0.05 ; \mathrm{CV}=\mathrm{Coefficient}$ of variation; ns $=$ not significant, ${ }^{* *}=$ significant at $\mathrm{p} \leq 0.01$, and ${ }^{*}=$ significant at $\mathrm{p} \leq 0.05$ by the $\mathrm{F}$ test 
layer, and similar between treatments in the $5-10 \mathrm{~cm}$ layer (Table 1). The soil $\mathrm{pH}$ was lower in FCC, which reflects the higher presence of $\mathrm{H}+\mathrm{Al}$ in this management system. Iwata et al. (2012) found increases in $\mathrm{pH}$ and decreases in aluminum saturation in agroforest systems when compared to FCC, and attributed these results to the soil organic matter, whose function is to complex free $\mathrm{H}^{+}$and $\mathrm{Al}^{3+}$ cations and add bases that increase the soil $\mathrm{pH}$. However, considering the similar organic matter contents found in SCC and FCC, the lower presence of $\mathrm{H}^{+}$and $\mathrm{Al}^{3+}$ in SCC can be explained by the release of bases due to a faster mineralization of organic matter, since no presence of lignified branches was found, only leaves.

Neves et al. (2007) found decreases in aluminum saturation and maintenance of $\mathrm{pH}$ in areas using intercrops with coffee plants, but reported that external nutrients are needed in intercrops to avoid soil chemical degradation. Ilany et al. (2010) found higher susceptibility to lowering of soil fertility over time in monocultures under agroforest systems.

The soil under SCC presented higher Ca content and $\mathrm{pH}$ and lower $\mathrm{H}+\mathrm{Al}$, even though it had no pruning residues and no external soil fertilization or liming, denoting the efficiency of the system in to maintain and improve the soil chemical quality.

The $\mathrm{K}, \mathrm{Ca}$, and $\mathrm{S}$ contents in the litterfall of the treatments SCC and FCC were similar (Figure 2); however, the $\mathrm{N}$ and $\mathrm{Mg}$ contents in the litterfall were higher in FCC, whereas $\mathrm{P}$ was higher in SCC, although with similar concentrations $-0.92 \mathrm{~g} \mathrm{dm}^{-3}$ for SCC, and $0.69 \mathrm{~g} \mathrm{dm}^{-3}$ for FCC. The nutrient content in the litterfall is usually dependent on the species present in the site, plant characteristics, and soil nutrient availability (Schumacher et al., 2004).

Nutrient concentrations $\left(\mathrm{g} \mathrm{dm}^{-3}\right)$ in the litterfall in the treatment SCC followed the order $\mathrm{Ca}>\mathrm{N}>\mathrm{K}>\mathrm{S}>\mathrm{Mg}>\mathrm{P}$, and in the treatment FCC it was $\mathrm{Ca}>\mathrm{N}>\mathrm{Mg}>\mathrm{K}>\mathrm{S}>\mathrm{P}$, based on estimates of amount of nutrients that will be added to the soil after the litterfall decomposition. Due to the translocation of some nutrients from leaves to other plant organs before their senescence, senescent leaves usually present higher $\mathrm{Ca}$ and $\mathrm{Mg}$ contents than $\mathrm{N}, \mathrm{P}$, and $\mathrm{K}$ contents (Boeger et al., 2005), which was found in the present study, except for nitrogen (Figure 2).

The soil under SCC presented higher basal respiration than that of the soil under FCC (Table 2), which is a result

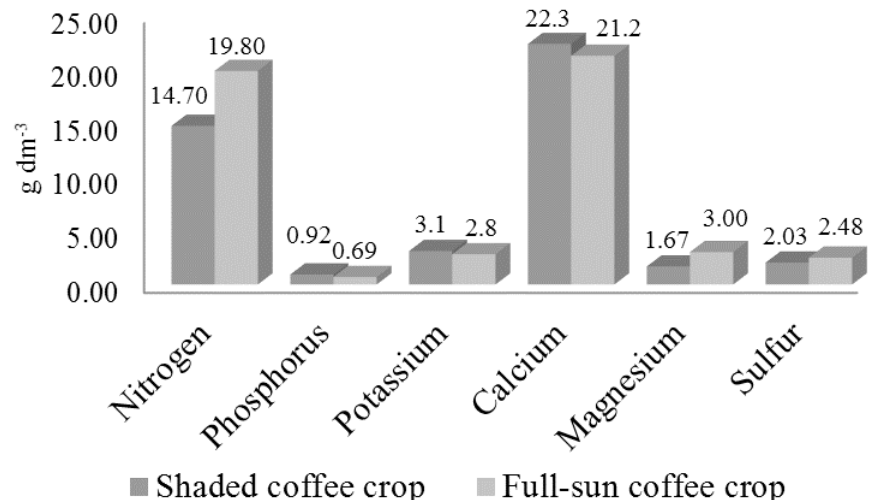

Figure 2. N, P, K, Ca, Mg, and S contents in the litterfall collected on soils under full-sun coffee crop (FCC) and shaded coffee crop (SCC) in the late summer of 2017/2018 represented by a higher $\mathrm{CO}_{2}$ release in the $0-5 \mathrm{~cm}$ soil layer. This denotes the occurrence of higher microbial activity in the shaded environment. The higher microbial activity in SCC can be attributed to the higher amount of leaves on the soil due to their senescence, either from coffee plants and the arboreous species, which occurs mainly in dry periods to minimize the effects of low water availability (Villa et al., 2015). These leaves form a thick layer that maintains the soil moisture and decreases the soil temperature (Silva et al., 2012; Pezarico et al., 2013; Silva et al., 2016; Guimarães et al., 2017).

This cover with plant residues formed on the soil creates a favorable environment to the development of microorganisms (Cunha Neto et al., 2013; Guimarães et al., 2017). Soils under agroforest systems present higher microbial activity than those under annual crops due to their organic matter quality in addition to microclimate factors higher soil moisture and low soil thermal amplitude that results in more stable temperatures (Silva et al., 2012). The association of coffee plants with teak in the present study was promising regarding increases in microbial activity; however, it was restricted to the first $5 \mathrm{~cm}$ of soil (Table 2).

According to Silva et al. (2016), water availability and temperature are the main controllers of the soil $\mathrm{CO}_{2}$ efflux. In the Amazon biome, the higher controller of this seasonal $\mathrm{CO}_{2}$ efflux is the soil water availability due to the low temperature variations over the year. Moreover, another factor is the composition of plant species, since it provides a favorable microclimate and participates in the addition of carbon.

Coffee crops intercropped with Tabebuia sp., Musa spp., and Acacia sp. presented similar microbial activity to those found for native vegetation, and higher than those found for coffee plants in single crops (Guimarães et al., 2017). This is consistent with the significant difference between the coffee plants intercropped with teak and the coffee plants in single crops under full sun. Guimarães et al. (2017) reported that coffee plants intercropped with other species presented higher soil basal respiration due to a higher quantity of residues from a biodiversity of plants, which stimulates the activity of microorganisms.

Another factor that contributed to the higher soil basal respiration in SCC in the surface layer, when compared to the FCC, is the herbicide application, which was done in FCC to control weeds; this management was not necessary in SCC. Melloni et al. (2013) compared different methods for weed control (manual hoeing, rotary tiller, harrowing, no hoeing, pre-emergence herbicide, and post-emergence herbicide) and found intermediate negative impact on biological attributes in coffee plants when applying pre-emergence herbicide, and higher negative effect on the interrow of coffee plants when applying post-emergence herbicide.

The soil basal respiration in the crop systems evaluated presented no significant difference in the $5-10 \mathrm{~cm}$ layer; however, the basal respiration in this soil layer was lower when compared to the surface layer (Table 2). This confirms the dependency of microbial activity on the presence of soil organic matter (Pinto Neto et al., 2014; Oliveira et al., 2015). 


\section{Conclusions}

1. The soil under the shaded coffee crop had higher Ca contents, $\mathrm{pH}$, and base saturation, and lower potential acidity and aluminum content than that under the full-sun coffee crop.

2. The litterfall under the full-sun coffee crop presented higher nitrogen and magnesium contents.

3. The soil basal respiration was higher in the first $5 \mathrm{~cm}$ of the soil and was higher in the that coffee crop under shade.

\section{ACKNOWLEDGeMents}

The coordenação de aperfeiçoamento de pessoal de nível superior (CAPES) for the financial support for the development of this project (Processo CAPES n ${ }^{\circ} 23038.021530 / 2016-35 /$ Projeto AUPEX n 1954/2016).

\section{Literature Cited}

Acosta, J. A. A.; Amado, T. J. C.; Silva, L. S.; Santi, A.; Weber, M. A. Decomposição da fitomassa de plantas de cobertura e liberação de nitrogênio em função da quantidade de resíduos aportada ao solo sob sistema plantio direto. Ciência Rural, v.44, p.1-9, 2014. https://doi.org/10.1590/S0103-84782014005000002

Alvares, C. A.; Stape, J. L.; Sentelhas, P. C.; Gonçalves, J. L. de G.; Sparovek, G. Köppen's climate classification map for Brazil. Meteorologische Zeitschrift, v.22, p.711-728, 2013. https://doi. org/10.1127/0941-2948/2013/0507.

Boeger, M. R. T.; Wisniewski, C.; Reissmann, C. B. Nutrientes foliares de espécies arbóreas de três estádios sucessionais de floresta ombrófila densa no sul do Brasil. Acta Botânica Brasilica, v.19, p.167-181, 2005. https://doi.org/10.1590/S010233062005000100017

Cunha Neto, F. V.; Santos Leles, P. S. S.; Pereira, M. G.; Bellumath, V. G. H.; Alonso, J. M. Acúmulo e decomposição da serapilheira em quatro formações florestais. Ciência Florestal, v.23, p.379-387, 2013. https://doi.org/10.5902/1980509810549

Ferreira, D. F. Sisvar: A guide for its bootstrap procedures in multiple comparisons. Ciência e Agrotecnologia, v.38, p.109-112, 2014. http://dx.doi.org/10.1590/S1413-70542014000200001.

Guimarães, N. F.; Gallo, A. S.; Fontanetti, A.; Meneghin, S. P.; Souza, M. D. B.; Morinigo, K. P. G.; Silva, R. F. Biomassa e atividade microbiana do solo em diferentes sistemas de cultivo do cafeeiro. Revista de Ciências Agrárias, v.40, p.34-44, 2017. http://dx.doi. org/10.19084/RCA16041.

Haggar, J.; Barrios, M.; Bolaños, M.; Merlo, M.; Moraga, P.; Munguia, R.; Ponce, A.; Romero, S.; Soto, G.; Staver, C.; Virginio, E. de M. F. Coffee agroecosystem performance under full sun, shade, conventional and organic management regimes in Central America. Agroforest System, v.82, p.285-301, 2011. https://doi. org/10.1007/s10457-011-9392-5.

Han, L.; Sun, K.; Jin, J.; Xing, B. Some concepts of soil organic carbono characteristics and mineral interaction from a review of literature. Soil Biology and Biochemistry, v.94, p.107-121, 2016. http:// dx.doi.org/10.1016/j.soilbio.2015.11.023.

IBGE - Instituto Brasileiro de Geografia e Estatística. Censo agropecuário. 2017. Available on: <https://sidra.ibge.gov.br/ pesquisa/censo-agropecuario/censo-agropecuario-2017>. Accessed on: Mar. 2018.
Ilany, T.; Ashton, M. S.; Montagnini, F.; Martinez, C. Using agroforestry to improve soil fertility: Effects of intercropping on Ilex paraguariensis (yerba mate) plantations with Araucaria angustifolia. Agroforest System, v.80, p.299-409, 2010. https://doi. org/10.1007/s10457-010-9317-8.

Iwata, B. F.; Leite, L. F. C.; Araújo, A. S. F.; Nunes, L. A. P. L.; Gehring, C.; Campos, L. P. Sistemas agroflorestais e seus efeitos sobre os atributos químicos em Argissolo Vermelho-Amarelo do Cerrado piauiense. Revista Brasileira de Engenharia Agrícola e Ambiental, v.16, p.730-738, 2012. https://doi.org/10.1590/S141543662012000700005.

Lima, R. P.; Fernandes, M. M.; Fernandes, M. R. M.; Matricardi, E. A. T. Aporte e decomposição da serapilheira na Caatinga no Sul do Piauí. Floresta e Ambiente, v.22, p.42-49, 2015. http://dx.doi. org/10.1590/2179-8087.062013.

Malavolta, E.; Vitti, G. C.; Oliveira, S. A. Avaliação do estudo nutricional das plantas: Princípios e aplicações. 2.ed. Piracicaba: Patafós, 1997. 319p.

Melloni, R.; Belleze, G.; Pinto, A. M. S.; Dias, L. B. P.; Silva, E. M.; Melloni, E. G. P.; Alvarenga, M. I. N.; Alcântara, E. N. Métodos de controle de plantas daninhas e seus impactos na qualidade microbiana de solo sob cafeeiro. Revista Brasileira de Ciência do Solo, v.37, p.67-75, 2013. https://doi.org/10.1590/S010006832013000100007

Neves, Y. P.; Martinez, H. E. P.; Souza, C. M.; Cecon, P. R. Teor de água e fertilidade do solo com cafeeiros cultivados em sistemas agroflorestais. Revista Árvore, v.31, p.575-588, 2007. https://doi. org/10.1590/S0100-67622007000400002

Oliveira, B. S.; Carvalho, M. A. C.; Lange, A.; Wruck, F. J. Dallacort, R. Atributos biológicos do solo em sistema de integração lavourapecuária-floresta, na região Amazônica. Revista Engenharia na Agricultura, v.23, p.448-456, 2015. https://doi.org/10.13083/14143984/reveng.v23n5p448-456.

Pezarico, C. R.; Vitorino, A. C. T.; Mercante, F. M.; Daniel, O. Indicadores de qualidade do solo em sistemas agroflorestais. Revista de Ciências Agrárias, v.56, p.40-47, 2013. http://dx.doi. org/10.4322/rca.2013.004.

Pinto Neto, J. N.; Alvarenga, M. I. N.; Corrêa, M. de P.; Oliveira, C. C. Efeito das variáveis ambientais na produção de café em um sistema agroflorestal. Coffee Science, v.9, p.187-195, 2014.

R Core Team. R: A language and environment for statistical computing. Vienna: R Foundation for Statistical Computing, 2015. Available on: <https://www.r-project.org > Accessed on: Out. 2018.

Raij, B. van; Andrade, J. C.; Cantarella, H.; Quaggio, J. A. Análise química para avaliação da fertilidade de solos tropicais. Campinas: Instituto Agronômico de Campinas, 2001. 284p.

Ribeiro, A. C.; Guimarães, P. T. G.; Alvarez V., V. H. Recomendações para o uso de corretivos e fertilizantes em Minas Gerais: $5^{\circ}$ aproximação. Viçosa: UFV, 1999. 359p.

Ricci, M. S. F.; Costa, J. R.; Oliveira, N. G. Utilização de componentes principais para analisar o comportamento do cafeeiro a pleno sol e sombreado. Coffee Science, v.6, p.44-54, 2011. http://dx.doi. org/10.25186/cs.v6i1.380.

Rodrigues, V. G. S.; Costa, R. S. C.; Leônidas, F. C.; Mendes, A. M. Sistemas agroflorestais com cafeeiro. In: Marcolan, A. L.; Espindula, M. C. (eds.). Café na Amazônia. Brasilia: Embrapa Informação Tecnológica, 2015. cap. 20, p. 435-446. 
Schumacher, M. V.; Brun, E. J.; Hernandes, J. I.; König, F. G. Produção de serapilheira em uma floresta de Araucaria angustifolia (Bertol.) Kuntze no município de Pinhal Grande-RS1. Revista Árvore, v.28, p.29-37, 2004. https://doi.org/10.1590/S0100-67622004000100005

Silva, C. M.; Vasconcelos, S. S.; Mourão Júnior, M.; Bispo, C. J. C.; Kato, O. R.; Silva Junior, A. C.; Castellani, D. C. Variação temporal do efluxo de $\mathrm{CO}_{2}$ do solo em sistemas agroflorestais com palma de óleo na Amazônia Oriental. Acta Amazonica, v.46, p.1-12, 2016. http://dx.doi.org/10.1590/1809-4392201500193.

Silva, E. E.; Azevedo, P. H. S.; De-Polli, H. Determinação da respiração basal (RBS) e quociente metabólico do solo $\left(\mathrm{qCO}_{2}\right)$. Seropédica: Embrapa Agrobiologia, 2007. 4p. Circular Técnica, 21
Silva, M. S. C; Silva, E. M. R.; Pereira, M. G.; Silva, C. F. Estoque de serapilheira e atividade microbiana em solo sob sistemas agroflorestais. Floresta e Ambiente, v.19, p.431-441, 2012. http://dx.doi.org/10.4322/floram.2012.058

Stefanoski, D. C.; Santos, G. G.; Marchão, R. L.; Petter, F. A.; Pacheco, L. P. Uso e manejo do solo e seus impactos sobre a qualidade física. Revista Brasileira de Engenharia Agrícola e Ambiental, v.17, p.13011309, 2013. http://doi.org/10.1590/S1415-43662013001200008

Villa, E. B.; Pereira, M. G.; Alonso, J. M.; Beutler, S. J.; Leles, P. S. S. Aporte de serapilheira e nutrientes em área de restauração florestal com diferentes espaçamentos de plantio. Floresta e Ambiente, v.23, p.90-99, 2015. http://dx.doi.org/10.1590/2179-8087.067513 